Vol.3 No.2 Hal. 108-113

September 2020
ISSN (Print) : $2614-8064$

ISSN (Online): $2654-4652$

\title{
Pengetahuan dan Pemanfaatan Limbah kain Perca Menjadi Masker Sebagai Pencegahan Covid-19
}

\author{
Elfrida $^{(1)}$, Erni Junaida ${ }^{(2)}$ \\ Pendidikan Biologi dan Ekonomi Manajemen \\ Fakultas Keguruan Dan Ilmu Pendidikan dan Fakultas Ekonomi \\ Universtias Samudra \\ $\underline{\text { elfrida@unsam.ac.id }}{ }^{(1)}, \underline{\text { ernijunaida@unsam.ac.id }}{ }^{(2)}$
}

\begin{abstract}
ABSTRAK
Proses kegiatan pengabdian yang dilaksanakan oleh tim pengabdian adalah untuk mengetahui pengetahuan masyarakat dalam memanfaatkan limbah kain perca dijadikan masker yang berguna bagi masyarakat sebagai pencengahan covid-19. Hal ini membuat tim pengabdian untuk memberikan pelatihan membuat masker dari limbah kain perca kepada ibu PKK Desa matang Teupah Kecamatan Bendahara Kabupaten Aceh Tamiang. Metode yang ditawarkan kepada ibu PKK dalam kegiatan pengabdian adalah pelatihan dengan cara berceramah menjelaskan proses pembuatan masker dari limbah kain perca. Sampel dalam kegiatan pengabdian ini berjumlah 30 ibu PKK yang dilatih oleh tim pengabdian. Pengumpulan data dilakukan dengan observasi, pelatihan dan angket pengetahuan dan pemanfaat setelah kegiatan pengabdian dilaksanakan. Hasil yang didapat dalam kegiatan pengabdian adalah pengetahuan dengan memperoleh nilai $82,4 \%$ ibu PKK mengetahui proses pembuatan masker dari pelatihan sedangkan pemanfaatan dengan nilai $68 \%$ dinyatakan sering memanfaatkan masker kain semenjak terjadinya penyebaran covid-19.
\end{abstract}

Kata Kunci : Masker, Kain Perca, Covid-19

\begin{abstract}
The process of community service activities carried out by the service team is to find out people's knowledge in utilizing patchwork waste to be used as masks that are useful for the community as covid-19 prevention. This led the community service team to provide training to make masks from patchwork waste to the PKK, Teupah Village, Bendahara District, Aceh Tamiang Regency. The method offered to PKK mothers in service activities is training by lecturing explaining the process of making masks from patchwork waste. The sample in this service activity was 30 PKK mothers who were trained by the community service team. Data collection was carried out by observation, training and questionnaires of knowledge and users after the service was carried out. The result obtained in service activities is knowledge by obtaining a score of $82.4 \%$, PKK mothers know the process of making masks from training while utilization with a value of $68 \%$ is stated to have often used cloth masks since the spread of Covid-19.
\end{abstract}

Keywords: Masks, Patchwork, Covid-19 
Elfrida, Juanida E : Pengetahuan dan Pemanfaatan Limbah Kain Perca Menjadi Masker Sebagai Pencegahan Covid-19

\section{PENDAHULUAN}

\section{Latar Belakang}

Pengetahuan masyarakat mengenai menjaga dan pemeliharaan kesehatan, dengan cara menghindari penyakit, maka akan meningkatkan pengetahuan masyarakat (Priyanto,2018). Pengetahuan memegang peranan penting untuk menentukan suatu sikap yang utuh, sebab pengetahuan itu akan membentuk suatu kepercayaan serta pengambilan keputusan tertentu (Novita dkk, 2018). Sedana dengan pendapat Prihantana, dkk (2016) yang menyatakan bahwa pengetahuan mempunyai suatu kaitan yang erat dengan keputusan terhadap pengetahuan pengetahuan seseorang memiliki landasan untuk menentukan pilihan. Pengetahuan ini juga berkaitan mengenai mewabahnya tentang penyakit Covid-19 yang sangat penting bagi masyarakat untuk disosialsaikan bahaya penularan covid-19. Maka dari itulah kita wajib memberikan pengetahuan kepada masyarakat untuk menjaga kesehatan yang pertama penggunaan masker. Hal ini menyebabkan kami sebagai tim pengabdian untuk memberikan pengetahuan masayarakat dengan memanfaatkan kain perca sebagai bahan dasar dalam membuat masker sebagai pencengahan covid-19. Kegiatan yang akan tim laksanakan di Desa Matang Teupah Kecamatan Bendahara Kabupaten Aceh Tamiang mempunyai suatu kelompok desa yaitu ibu PKK. Kelompok ibu PKK didesa Matang Teupah dalam tidak aktif dalam kegiatan, hal ini kita ketahui bahwa tim pengabdian sebelum melaksanakan kegiatan pengabdian melakukan survey lapangan terlebih dahulu. Kegiatan pengabdian yang akan kami laksanakan belum pernah mendapatkan pelatihan bagaimana memanfaatkan limbah kain (perca) menjadi produk yang bekualitas. Permasalahan pemasaran juga terkendala, tidak pernah ada pelatihan pengetahuan masyarakat khususnya ibu PKK bagaimana cara memasarkan produk yang telah dibuat untuk menambah perekonomian keluarga, dalam menghadapi perekonomian covid-19. Oleh sebab itulah keterampilan dalam membuat produk limbah dari kain perca ini, masyarakat khususnya bagi $\mathrm{ibu}$ - ibu rumah tangga menjadi peluang usaha. Adapun produk yang dihasilkan bernilai guna adalah masker. Kegiatan pengabdian membuat masyarakat mendapat pengetahuan dan meningkatkan kreativitas pemanfaatan kain perca menjadi masker adalah solusi yang cukup baik untuk mengubah limbah menjadi barang yang berguna kembali, bahkan memiliki nilai jual serta dapat dikreasikan menjadi barang yang mempunyai nilai estetika. Dengan adanya program kegiatan pelatihan pemanfaatan limbah kain perca menjadi masker ini diharapkan dapat meningkatkan kepedulian terhadap lingkungan, selain itu warga dapat mempunyai keterampilan dalam hal kreativitas serta dapat meningkatkan kesejahteraan warganya. Kegiatan pengabdian ini juga dapat menambah penghasilan pendapatan perekonomian keluarga, yang menjadi peluang usaha. Apalagi seorang ibu rumah tangga yang tidak mempunyai pekerjaan hanya mengharapkan pendapatan suami, kegiatan ini dapat menambahkan pendapatan suami.

\section{Perumusan Masalah}

Adapun permasalahan yang dihadapi oleh mitra dalam kegiatan pengabdian dapat diungkapkan secara umum yaitu (1) Belum adanya pelatihan mengenai produk kain perca;

(2) Keterbatasan ibu PKK mempunyai keterampilan dalam pengolah berbagai macam produk berbahan dasar kain perca; (3) Kurangnya pengetahuan ibu PKK dalam metode pemasaran produk secara online.

\section{Tujuan Penelitian}

Untuk mengatasi problema tersebut dengan memotivasi ibu PKK Desa Matang Teupah selaku mitra yaitu (1) Memberikan pelatihan dan pendamping kepada ibu PKK dalam membuat produk produk berbahan dasar kain perca; (2) Melakukan pendampingan dalam 
Elfrida, Juanida E : Pengetahuan dan Pemanfaatan Limbah Kain Perca Menjadi Masker Sebagai Pencegahan Covid-19

pemasaran melalui sosial media social; (3) Adanya tempat untuk dijadikan tempat usaha bagi Ibu-Ibu PKK di Desa Matang Teupah.

\section{Manfaat Penelitian}

Dimana kegiatan ini ibu rumah tangga dapat pengetahuan baik dari keterampilan maupun pengetahuan pemasaran produk dalam berwirausaha. Berkaitan dengan hal ini maka tim pengabdian akan membuat suatu pelatihan bagi masyarakat khususnya ibu rumah tangga dari segi pengetahuan keterampilan dalam membuat masker yang dapat dimanfaatkan sebagai pencengahan covid-19 dan juga sebagai peluang usaha pendapatan keluarga.

\section{METODE PENELITIAN}

Metode yang diterapkan untuk mengatasi permasalahan mitra adalah (1) menggunakan strategi ceramah sebagai (penyuluhan) mengenai kewirausahaan; (2) pelatihan dalam ketrampilan berkreasi serta berinovasi dalam membuat masker dari kain perca, (3) pengembangan fasilitas proses produksi masker dari kain perca, (4) melakukan pendampingan dan praktek pembuatan masker dari kain perca, (5) pembuatan buku panduan yang berisi petunjuk pembuatan bermacam-macam masker dari kain perca. Pengumpulan data dalam kegiatan pengabdian ini yaitu (1) observasi; (2) pelatihan; (3) angket.

\section{HASIL DAN PEMBAHASAN}

\section{OBSERVASI}

Pada tanggal 01 Agustus 2020 tim pengabdian melakukan observasi ke lokasi pengabdian. Pada waktu itu tim menjumpai datok Desa Matang Teupah Kecamatan Bendahara Kabupaten Aceh Tamiang, terjadilah diskusi untuk menentukan kegiatan pengabdian. Kegiatan itu dilaksanakan kepada ibu PKK sebagai peserta pengabdian kepada masyarakat.

\section{PELATIHAN}

Proses kegiatan pengabdian yang dilakasanakan oleh tim pengabdian adalah berupa pelatihan dengan memberikan pengetahuan kepada ibu PKK dalam memanfaatkan limbah kain perca menjadi produk bernilai ekonomis yaitu masker sebagai pencengahan pertama penyebaran covid-19. Adapun hasil kegiatan dilaksanakan dapat terlihat pada gambar di bawah ini.

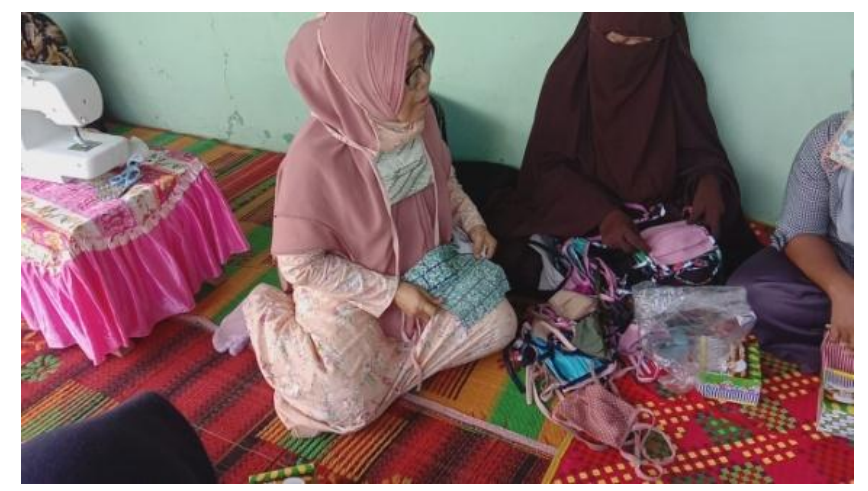

Gambar 1. Pembuatan pola kain untuk produk masker

Gambar 1 ini menjelaskan kepada ibu PKK sebagai peserta dalam pelatihan pembuatan masker. Tahap awal pelatihan tim pengabdian menjelaskan bagaimana cara membuat pola kaian untuk membuat maskel yang dijelaskan oleh ketua tim pengabdian Dra. Elfrida, M.Pd. selanjutnya tahap kedua dapat dilihat pada gambar di bawah ini. 
Elfrida, Juanida E : Pengetahuan dan Pemanfaatan Limbah Kain Perca Menjadi Masker Sebagai Pencegahan Covid-19

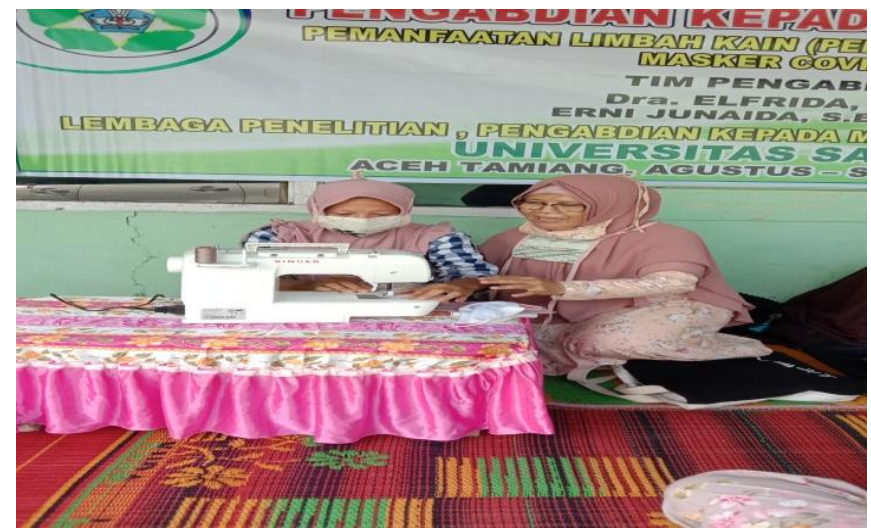

Gambar 2. Menjahit masker

Berkaitan mengenai gambar 2 diatas ketua pengabdian menjelaskan dan mepraktekkan kepada salah satu ibu PKK cara menjahit membuat masker yang telah dibuat pola dari kain perca tersebut. Tahap ke tiga dapat terlihat pada gambar di bawah ini.

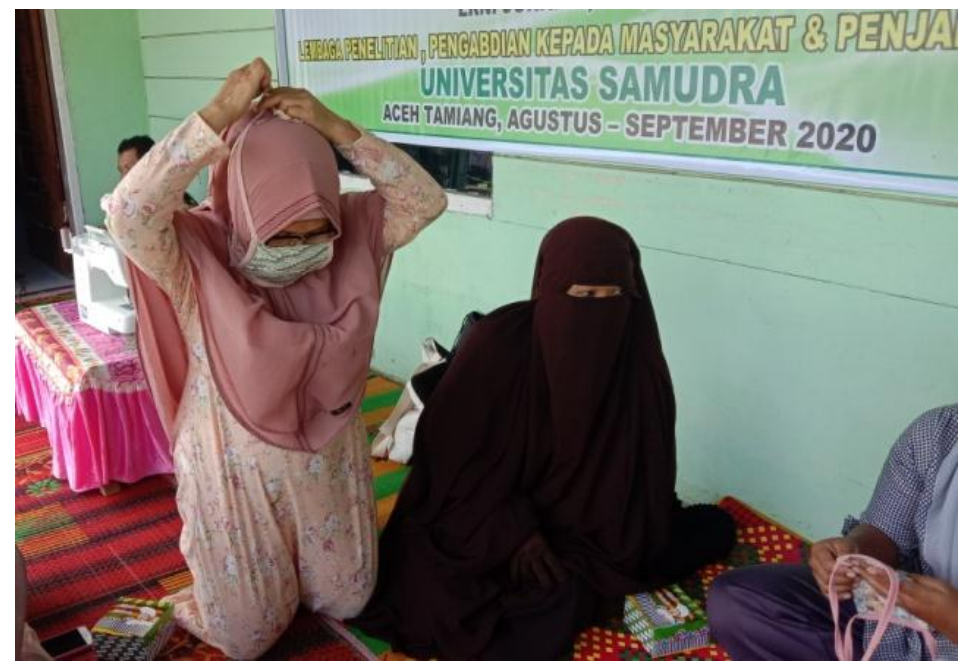

Gambar 3. Menjelaskan dan mempraktekan cara memakai masker

Pada tahap ini tim pengabdian yang dipraktekkan oleh ketua tim pengabdian ibu Dra, Elfrida, M.Pd menjelaskan bagaimana cara memakai masker yang telah dibuat dari hasil pelatihan kepada ibu PKK.

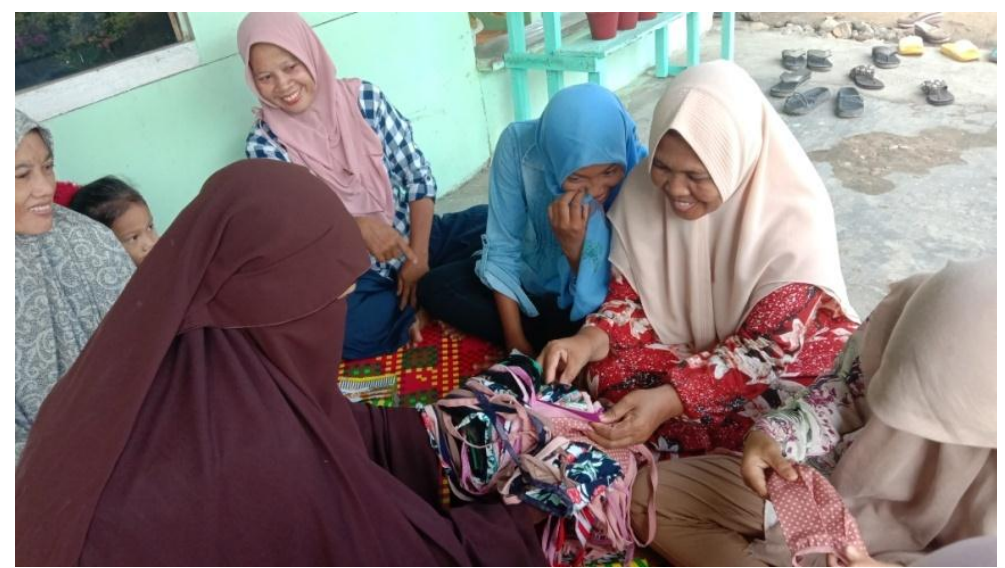

Gambar 4. Pembagian masker kepada ibu PKK

Pada gambar 4 tahap ini membagikan masker yang telah dibuat dari tim pengabdian berserta ibu PKK untuk dipakai dan dimanfaatkan sebagai pencengahan covid-19. 
Elfrida, Juanida E : Pengetahuan dan Pemanfaatan Limbah Kain Perca Menjadi Masker Sebagai Pencegahan Covid-19

\section{ANGKET}

Berdasarkan pada gambar diatas mengenai proses pelatihan pada tahap awal sampai akhir. Tim pengabdian mengukur angket pengetahuan dan pemanfaat kain perca dijadikan masker dari hasil kegiatan pelatihan yang diberikan oleh tim pengabdian kepada masyarakat. Hasil dari angket tersebut dapat terlihat pada gambar grafik di bawah ini.

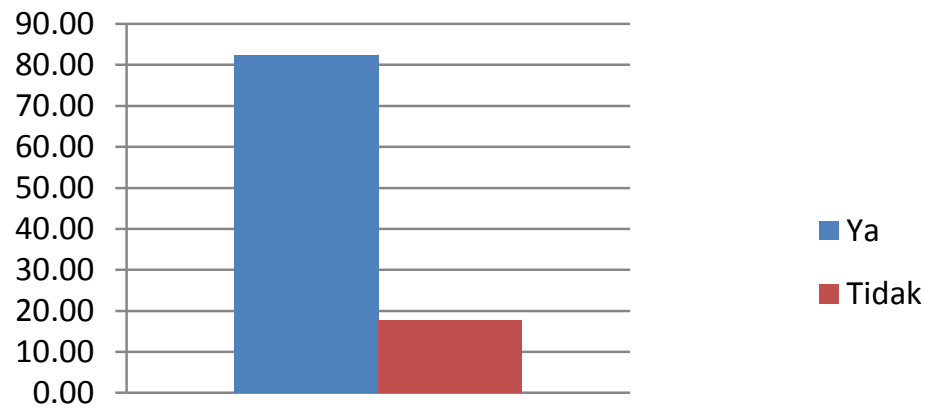

Gambar 5. Angket pengetahuan

Hasil dari kegiatan tim pengabdian kepada masyarakat mengukur pengetahuan ibu PKK proses pembuatan masker dari limbah kain perca sebagai pencengahan covid-19 menyatakan hasilnya sebanyak $82,4 \%$ yang menjawab Ya mengetahui proses pembuatan masker setelah kegiatan pelatihan cara membuat masker.

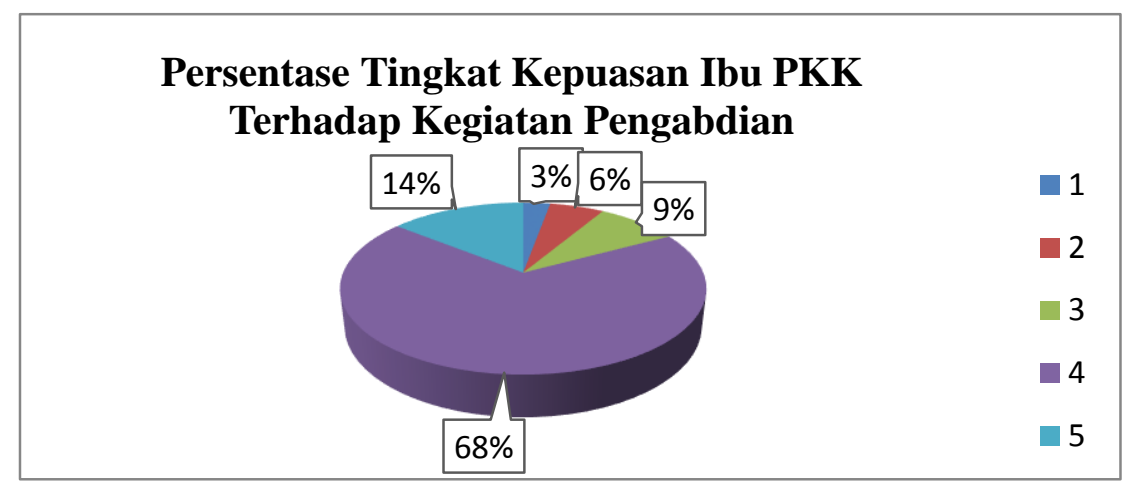

Gambar 5. Angket kepuasan

Berdasarkan hasil angket pemanfaatan yang terdiri dari lima alternatif jawaban dapat dijelaskan bahwa 14\% dinyakan sangat sering, 68\% dinyatakan sering, 9\% dinyatakan kadang - kadang, 6\% dinyatakan tidak pernah, 3\% sangat tidak pernah

\section{KESIMPULAN}

Hasil dari kegiatan pengabdian dapat disimpulkan yaitu (1) angket pengetahuan dengan nilai 82,4 yang menjawab Ya, maka dapat disimpulkan baik pengetahuan ibu PKK setelah kegiatan pelatihan pengabdian proses pembuatan masker; (2) angket pemanfaatan sering dengan nilai $68 \%$ maka dinyatakan ibu PKK sering memanfaatkan masker kain semenjak terjadinya penyebaran covid-19. 
Elfrida, Juanida E : Pengetahuan dan Pemanfaatan Limbah Kain Perca Menjadi Masker Sebagai Pencegahan Covid-19

\section{DAFTAR PUSTAKA}

Kak Muksin, Yuk Membuat Alat Peraga Edukatif dari Barang Bekas, Diva Press, Jakarta Lubna Fatiha, Souvenir dari Perca, Trubus Agrisarana, Surabaya.

Novita, dkk. 2014. Tingkat Pengetahuan Tentang TB Paru Mempengaruhi Penggunaan Masker Di Ruang Paru Rumkital Dr. Ramelan Surabaya. Jurnal Ilmiah Kesehatan. Vol 7. No. 12. Surabaya: STIKES Hang Tuah.

Prihantana, dkk. 2016. Hubungan Pengetahuan Dengan Tingkat Kepatuhan Pengobatan Pada Pasien Tuberkolosis Di RSUD Dr. Soehadi Prijonegoro Sragen. Jurnal Farmasi Sains Dan Praktis. Vo. 2. No. Poltekkes Bhakti Mulia.

Priyanto, Agus. 2018. Hubungan Tingkat Pengetahuan Dengan Perilaku Pencegahan Kekambuhan Luka Diabetik. Jurnal Ners Dan Kebidanan. Vol. 5 No. 3. Kediri : STIKES Ganesha Husada.

Rifki Azis dan Nurheti Yuiarti, Bisnis menggiurkan dari kain perca, Gramedia Pustaka Utama, Jakarta.

\begin{tabular}{|l|l|l|l|}
\hline Accepted Date & Revised Date & Decided Date & Accepted to Publish \\
\hline 17 Agustus 2020 & 19 Agustus 2020 & 23 Agustus 2020 & Ya \\
\hline
\end{tabular}

